\title{
Nexus between Public Finance and Economic Growth in Nigeria
}

\author{
PEACE ONYEDIKACHI CHIMEZIE ${ }^{1 \mathrm{a}}$, EHIMARE ALEXXNDER OMANKHANLEN ${ }^{1 \mathrm{~b}}$, \\ SYLVESTER ERIABIE \\ ${ }^{1}$ Department of Banking and Finance, Covenant University, Ota, NIGERIA \\ ${ }^{2}$ Department of Accounting, Covenant University, Ota, NIGERIA
}

\begin{abstract}
Public finance deals with various roles and activities of the government aimed at ensuring economic growth. This study assessed the nexus between public finance and economic growth in Nigeria. It adopts the theory of Peacock; it states that a country could evolve after encountering social disturbances. Such financial difficulties are expected to increase government spending leading to national growth. Secondary data sources gotten from CBN and World Development Indicators are used. Data analysis is done using Unit Root test, Auto-Regressive Distributed Lag (ARDL) and granger causality technique for period 1981 to 2017. Results of the study indicate that Government revenue (GREV) has a major effect on development of Nigeria's economy, Government expenditure (GEXP) has not substantially but significantly impacted economic growth via the outcomes of Recurrent expenditure(REXP) and capital expenditure (CEXP), and in conclusion Gross domestic savings (GDS) has not impacted Nigeria's economic growth. The recommendation made based on the findings are; In order to ensure aggregate productive public expenditures, the government of Nigeria should ensure that the composition of public sector outputs is optimal. This can be done by ensuring it does not produce either too much of one good or too little of another,the government of Nigeria through various investment schemes and programs that are tax exempt can promote the practice of saving in the country. Investing in such saving schemes can considerable promote individuals tax savings which in turn increases gross domestic savings.
\end{abstract}

Key-Words:- Public finance, government revenue, nexus, economic growth.

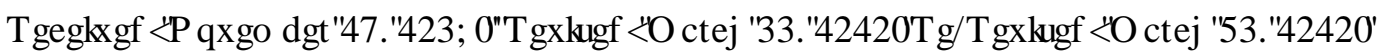

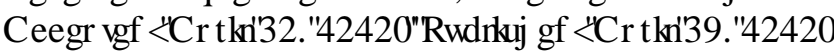

\section{Introduction}

Public finance is a general economy division dealing with the government economic operations at national, state, and local level. It is the study of central, state and local public revenue and expenditure and the principles underlying it. According to (Dalton, 1922), "Public finance centres on public authorities ' income and expenditure and the transfer of one to another."'This whole concept has to do with the process of raising and disbursing funds, collection of revenue and it's spending for government functioning.

The provision of public products, stability, growth and government curtailment, and the actual impacts of inflation, has now been so significantly extended by public finance. Public finance will always provide sufficient food for thought on the key scarcity problem and the related growth and allocation problems. The size and structure of government spending will affect pattern, shape of governance and growth of an economy.(Smriti, 2017)

\subsection{Statement of Problem}

Public finance can be seen as encompassing all fiscal policy provisions and activities that promote fiscal policy's macroeconomic objectives, especially long-term economic growth. To accomplish these results, it is necessary that government funds are efficiently and effectively utilized. At the same moment, a government is expected to perform spending and income strategies in such a manner that incentives are created for the effective functioning of labour, products and services markets.

However, a look into the last decade public expenditure shows that the government of Nigeria has not displayed effective or efficient use of its expenditure. Analysis from CBN statistical bulletin shows a spontaneous increase without a corresponding impact on overall sector of the economy. A look at the last 10 years figures from 2007-2017 shows a clear data of the rising expenditure of government. In 2007 the total amount of government expenditure was 2,348.55 Billion, in 2008 it was $\$ 3,078.25$ Billion, and in 2009 it 
rose to $\$ 3,280.76$ Billion, in 2010 it was $\$ 3,993.31$ Billion, in 2011 it was $\$ 4,233.06$ Billion, 2012 it declined a little to $\$ 4,199.86$ Billion, in 2013 it was $\$ 4.323 .34$ Billion, 2014 it was $\$ 4.210 .06$ Billion, 2015 it was $\$ 4,650.30$ Billion, in 2016 it was 4,813.71 Billion, in 2017 it was $\$ 6,022.28$ Billion.(CBN Statistical Bulletin, 2018).

Nigeria's economy suffers from public finance mismanagement. Nigeria has had a high degree of resource mismanagement, especially in the aspect of public fund disbursement. Contracts are awarded without due process and no proper checks and balance, abuses and negligence of rules and standards has been the order of the day. This is evident in over-invoicing, contract cost inflation, and proliferation of white-elephant projects, and public funds diversion amongst others. According to(Oyedele, 2016), the Joint Tax Board (JTB), records More than 10 million Nigerians (10,006,306 in particular) enrolled for personal income tax purposes in all federal states, including the FCT. These funds generated by government this tax is one amongst the source government revenue and other direct and indirect means yet no meaningful evidence is seen in the infrastructure development of the country and high unemployment rate has been the order of the day. This poses the real question as to why public finance has not significantly impacted Nigeria's economic growth.

\subsection{Research Question}

Based on the of statement the following questions emanates;

1. To what extent has government revenue impacted on economic growth in Nigeria?

2. What is the impact of government expenditure on economic growth in Nigeria?

3. How has gross domestic savings impacted on the economic growth of Nigeria?

\subsection{Objective of the Study}

The particular goals are as follows:

1. To determine whether revenue from government has impacted on Nigerian growth.

2. Examine whether government expenditure has resulted in the growth of Nigeria's economy.

3 To determining the impact of gross domestic savings on the economy of Nigeria.

\subsection{Hypothesis of Study}

This research's hypotheses are stated in $\left(\mathrm{H}_{0}\right)$ null form:
1. $\mathrm{H}_{0}$ : Revenue from government has no significant influence on Nigeria's economic growth.

2. $\mathrm{H}_{0}$ : Government expenditure has no significant effect on Nigeria's economic growth.

3. $\mathrm{H}_{0}$ : Gross domestic saving by government has no significant impact on Nigeria's economic growth.

\subsection{Scope of the Study}

This study investigates the relationship between the public finances and Nigeria economic growth. This includes taking advantage of macroeconomic determinants including GDP as an economic growth indicator, re-current expenditure (REXP), capital expenditure (CEXP), government revenue (GREV), and gross national savings (GDS_LCU).Information on the above factors will cover the periods from 1981 to 2017.

\section{Literature Review}

The review of literature will provide an insight into the study's associated literature and theoretical framework. This will serve as a basis for analytical debate of the topic and will boost the level of overall nexus awareness between Nigeria's public finance and economic growth.

\subsection{Conceptual Review}

Public finance can be seen as encompassing all fiscal policy provisions and activities that promote fiscal policy's macroeconomic objectives, especially long-term economic growth. To accomplish these results, it is necessary to use government funds efficiently and effectively.(Barrios \& Andrea, 2008)

\subsubsection{Government Expenditure}

Government expenditure consists of re-current expenditure and capital expenditure. Re-current has to do with the running cost of government such as salaries of government employees, wages, interest or charges, public debt and other transfer of government. Capital expenditure involves certain expenditure on capital projects such as building new highways, schools, hospitals, new machinery, military hardware, factory equipments and so on. (Ola \& Offiong, 1999)

\subsubsection{Government Revenue}

Revenue obtained by various departments, agencies of federal, state and local governments is 
referred to as administrative revenue. They include fees, licenses, fines, rates, royalties etc. (Ola \& Offiong, 1999).

\subsubsection{Economic Growth}

Economic growth can be described as a long-term rise in the physical production of a country. Economic growth of one country can be defined as the skill of the economy to boost the productivity of services and products compared to the previous period.

\subsection{Theoretical Underpinnings \\ 2.2.1 Adolf Wagner's Hypothesis}

Adolf Wagner launched the public spending hypothesis in 1890. According to Wagner, as the economy grows, there are inherent tendencies for growth both intensively and extensively in government activities. Invariable greater public spending rises automatically, resulting in a gradual rise in financial development. Other reasons that increase the trend of public spending include planning, upgrading, greater social demand and industrial growth, etc(Ajibola, 2008)

\subsubsection{The Argument of Peacock and Wiseman}

Peacock and Wiseman's theory of public spending was founded on their empirical investigations in the UK from 1890, 1955 and 1962. Both narrate the connection between an economy's development and government spending. According to this hypothesis, in an economy there are three fundamental impacts that can be seen from a country's increasing trajectory. They include;
a) Displacement impact
b) Inspection effect, and
c) Concentration effect.

\subsection{Empirical Review}

Empirical evidence supporting the impact of public finance by (Sobiech, Remittances, finance and growth, 2019)found no written agreement on the long-term effect of government finance on economic development.

However, past examinations have revealed that it may be identified with financial development in the exchange getting nation, yet the course of the connection stayed vague. Finding from the inquiry shows that the more financially a country is constructed up, the less the impact on financial development of government resources.

Empirical studies on the golden rule of government finance (Kamiguchi\&Toshiki,
2019).Using the overlapping generation system (OLS) of debt-financed public investment, their model recognizes that policy is based on the principle that is the golden rule of public finance. This revealed that maximization speed of growth is not proportional to maximizing levels of welfare; however, together the tax rates are lesser than the yield versatility of public capital.

The study by (Zeyneloglu, 2018)Reviews the efficiency of fiscal policy and Public Finance Golden Rule. The primary policy Is identified as the Golden Rule of Finance that allows part of government revenue to move upward in complete government expenditure, but restricts the use of government debt solely for investment reasons. Numerical results reveal that, under this golden principle, a fiscal expansion prompts a greater yield increase while maintaining a small degree of public debt in contrast to the subsequent norm.

In a research conducted by (Coskun, Unal, Murat, \& Talat, 2017).They explore the link between capital market sub-segments ' level of development, including reserves for common / benefits, corporate safety, stock and public safety markets, and national development. The outcomes demonstrated a longterm link between Capital market creation, and economic growth.

A study by (Kumar, Dogga, Mahandra, \& Avipsa, 2017) on the long-term link between savings and economic growth investigates causality problems in Indian settings from 1950-51 to 2011-12. The experimental proof of the investigation suggests that savings contribute to true movement in the long run, both in the pre- and post-break age, while economic growth leads to pre-break savings.

In a study carried out by (Szarowska, 2016)on the Quality of Czech Republic's public finances and economic growth. The study's purpose was to ascertain whether the main mediums and instruments employed by government finance (revenue framework structure, size of administration and usage, level and financial position support capacity) influences national growth of Czech Republic during the era 1995-2013.Observational framework relies on the Barro and Sala-I-Martin (2003) method and Mankiw et al. (1992) model that is adjusted to this examination's design. Effects of vibrant relapses imply that monetary growth is influenced mainly by open account variables and usual economic development wellsprings (human resources or transparency) are assumed. If resultant proof indicates that all out tax rate and revenue framework structure (especially certain expenditure rates on job 
and usage) should basically be used as machinery for maintaining macroeconomic destinations.

Omankhanlen, Ogaga, Oghene, Obarisiagbon \& Okorie (2014) examined the Nigerian government expenditure on Human Capital Development. As indicated by the investigation the degree of human capital improvement, is an impression of the degree of wellbeing and instruction of a country and it influences the degree of financial exercises in that country. The study looked at how effective government spending on human capital development in Nigeria was from 1990 to 2011 with particular focus on the human capital advancement education section. The result uncovered evidence from the Nigerian system's low quality schooling.

\section{Methodology}

Time series data analysis using Unit Root test, Auto-Regressive Distributed Lag (ARDL) and granger causality technique via E-Views statistical software (version 9.0) for period between 1981 and 2017 was done for this study.

\subsection{Model Specification}

Implicit form: GDP = $\mathrm{f}$ (GREV, REXP, CEXP, GDS_LCU, RINT, INFL, OEXR) ------- (1)

Re-stating equation (1) in its explicit and econometric form, we have:

GDP $=\beta_{0}+\beta_{1}$ GREV $+\beta_{2}$ REXP $+\beta_{3}$ CEXP + $\beta_{4}$ GDS_LCU $+\beta_{5}$ RINT $+\beta_{6}$ INFL $+\beta_{7}$ OEXR + $\mu \mathrm{t}(2)$

ARDL Model: $\triangle G D P_{t}=\beta_{0}+\sum_{i=0}^{n} \Delta \beta_{1} G R E V_{t_{-1}}+$ $\sum_{i=0}^{n} \Delta \beta_{2} R E X P_{t-1}+\sum_{i=0}^{n} \Delta \beta_{3} C E X P_{t-1}+$

$\sum_{i=0}^{n} \Delta \beta_{4} G D S_{-} L C U_{t_{-1}}+\sum_{i=0}^{n} \Delta \beta_{5} R I N T_{t-1}+$

$\sum_{i=0}^{n} \Delta \beta_{6} I N F L_{t-1}+\sum_{i=0}^{n} \Delta \beta_{7} O E X R_{t-1}$

$+\sum_{i=0}^{n} \beta_{8} G R E V_{t-1}+\sum_{i=0}^{n} \beta_{9} R E X P_{t-1}+$

$\sum_{i=0}^{n} \beta_{10} C E X P_{t_{-}-1}+\sum_{i=0}^{n} \beta_{11} G D S_{-} L C U_{t-1}+$

$\sum_{i=0}^{n} \beta_{12} R I N T_{t-1}+\sum_{i=0}^{n} \beta_{13} I N F L_{t_{-}-1}+$

$\sum_{i=0}^{n} \beta_{14} O E X R_{t_{-}-1}+\varepsilon_{t}$

Where;

$\mathrm{Y}=$ Gross Domestic Product (GDP)

$\mathrm{X}=$ Public Finance $(\mathrm{PF})$

$\beta_{1}=$ Government Revenue (GREV), $\beta_{2}=$

Recurrent Expenditure (REXP)

$\beta_{3}=$ Capital Expenditure (CEXP), $\beta_{4}=$

Gross Domestic Savings_LCU (GDS)

Other control variables: $\beta_{5}=$ Interest Rate (RINT), $\beta_{6}=$ Inflation

(INFL), $\beta_{7}=$ Exchange rate (OEXR),

$\beta_{0}=$ constant of the equation

$\beta=$ coefficient of the independent variable

$\mu \mathrm{t}=$ residual values or error term

\subsection{Empirical Results}

This includes analyzing, interpreting information and presenting research methodology results. Data analysis is done using Unit Root test, ARDL and granger causality technique via E-Views 9.0 statistical software for period between 1981 and 2017.

\subsubsection{Unit Root Stationary Tests}

Augmented Dickey-Fuller (ADF) unit root stationarity test findings are shown below:

Table 1. Unit Root Test

\begin{tabular}{|l|l|l|l|}
\hline VARIABLES & T-STAT & $\begin{array}{l}\text { P- } \\
\text { VALUE }\end{array}$ & $\begin{array}{l}\text { INTEGRATION } \\
\text { ORDER }\end{array}$ \\
\hline GDP & -4.893179 & 0.0003 & $\mathrm{I}(0)$ \\
\hline GREV & -3.523306 & 0.0148 & $\mathrm{I}(1)$ \\
\hline REXP & -4.291640 & 0.0018 & $\mathrm{I}(1)$ \\
\hline CEXP & -7.354957 & 0.0000 & $\mathrm{I}(1)$ \\
\hline GDS_LCU & -3.396981 & 0.0186 & $\mathrm{I}(1)$ \\
\hline RINT & -5.961293 & 0.0000 & $\mathrm{I}(0)$ \\
\hline INFL & -5.514745 & 0.0001 & $\mathrm{I}(1)$ \\
\hline OEXR & -3.297372 & 0.0227 & $\mathrm{I}(1)$ \\
\hline
\end{tabular}

Source: Authors Computations, (2019). E-views, 9.0

Table 1 Unit Root Test demonstrates that variables (GREV, REXP, CEXP. GDS LCU, INFL, OEXR) are integrated in the order of 1 while GDP and RINT are stationary at level. Hence, the ARDL technique is utilized to ascertain short and long-term relationship between variables due to mixed order 0 and 1 stationarity. 
Table 2. Short-Run ARDL Result

\begin{tabular}{lrcrr}
\hline \hline \multicolumn{1}{c}{ Variable } & Coefficient & Std. Error & t-Statistic & Prob.* \\
\hline \hline GDP(-1) & -0.000272 & 0.176703 & -0.001538 & 0.9988 \\
GREV & 0.027769 & 0.007564 & 3.671228 & 0.0019 \\
GREV(-1) & -0.022058 & 0.011096 & -1.987971 & 0.0632 \\
GREV(-2) & 0.068221 & 0.024081 & 2.832931 & 0.0115 \\
REXP & -0.049936 & 0.019028 & -2.624367 & 0.0178 \\
REXP(-1) & 0.025871 & 0.017595 & 1.470355 & 0.1597 \\
REXP(-2) & -0.071587 & 0.030003 & -2.386033 & 0.0289 \\
CEXP & 0.005829 & 0.017563 & 0.331912 & 0.7440 \\
CEXP(-1) & -0.043480 & 0.020586 & -2.112109 & 0.0498 \\
GDS_LCU & $1.90 \mathrm{E}-12$ & $8.48 \mathrm{E}-13$ & 2.236856 & 0.0390 \\
GDS_LCU(-1) & $-1.29 \mathrm{E}-12$ & $7.80 \mathrm{E}-13$ & -1.648347 & 0.1176 \\
GDS_LCU(-2) & $1.75 \mathrm{E}-12$ & $1.16 \mathrm{E}-12$ & 1.513545 & 0.1485 \\
RINT & 0.265725 & 0.085123 & 3.121643 & 0.0062 \\
INFL & 0.060410 & 0.082922 & 0.728522 & 0.4762 \\
INFL(-1) & 0.132794 & 0.072590 & 1.829380 & 0.0849 \\
OEXR & 0.342094 & 0.087093 & 3.927920 & 0.0011 \\
C & -2.377254 & 2.673654 & -0.889141 & 0.3863 \\
\hline \hline R-squared & 0.702963 & Mean dependent var & 4.148644 \\
Adjusted R-squared & 0.423399 & S.D. dependent var & 7.212710 \\
S.E. of regression & 5.476917 & Akaike info criterion & 6.545815 \\
Sum squared resid & 509.9425 & Schwarz criterion & & 7.308995 \\
Log likelihood & -94.27885 & Hannan-Quinn criter. & 6.806081 \\
F-statistic & 2.514497 & Durbin-Watson stat & 2.184964 \\
Prob(F-statistic) & 0.033916 & & & \\
\hline \hline & & & & \\
\hline
\end{tabular}

Source: Authors Computations, (2019). E-views, 9.0

Table 2 Illustrates that the first period lag of GDP at 5 percent is statistically insignificant. In addition, a one-year rise in GDP will result in a decline of about 1 percent in present GDP.

GREV: At 5 percent, GREV is statistically significant ast-stat is above 2 and p-stat is below 0.05.A percent rise in government revenue will cause about 3 percent increase in current GDP. This conforms to theory, because higher GREV is expected to boost economic growth since it implies more available income to spend on essential products and utilities needed in the economy. GREV for one period ago is statistically insignificant and causes about 2.2\% decline in present economic growth. Meanwhile, GREV for two periods ago is statistically significant and positively impacts the Nigerian economy by about $6.8 \%$. This indicates that government revenue for two years ago was possibly put to good use for it to still impact Nigeria's economic growth.

REXP:REXP has statistical insignificance at 5\% level as t-stat surpasses 2 and p-value is not up to 0.05 . A percentage rise in recurrent expenditure will bring about 5 percent reductions in current GDP. This negative relationship conforms to apriori expectation as higher recurrent expenses will adversely impact economic growth, given that most funds will be channeled to salaries and other costs which do not necessarily foster increased growth in the economy. However, recurrent expenditure for one year back is insignificant and positively impacts the Nigerian economy by about $2.6 \%$. Contrarily, REXP for two years ago is significant and negatively affects the economy by about $7.16 \%$.

CEXP: CEXP is statistically insignificant as t-stat falls below 2 and p-value exceeds 0.05 . One percent rise in capital expenditure results in increased economic growth by approximately $1 \%$. This is consistent with theory as greater capital spending is supposed to boost economic growth, since capital equipment benefit production and living standards in numerous ways. Nonetheless, CEXP for one year ago despite having statistical significance adversely hampers current economic growth by about $4 \%$, thereby implying that the capital goods purchased during that time frame were not beneficial to national production and growth.

GDS_LCU: This has statistical significance as t-stat is over 2 and p-value is beneath 0.05 . One percentage increase in gross domestic savings will lead to about 1.90 percent rise in total national savings. This positive relationship conforms to apriori expectation as higher savings will translate into higher growth as long as the savings are channeled into productive uses. Notwithstanding, GDS_LCU for one and two years back are both statistically insignificant. Nonetheless, aggregate domestic savings for one period ago is negatively related to current GDP while that of two periods ago positively affects current GDP.

RINT: At 5 percent, RINT is statistically significant as t-stat is above 2 and p-stat is below 0.05.A percentage rise in real interest rate will yield about 27 percent increase in current GDP. This positive relationship does not conform to theory, because a greater interest rate raises borrowing costs and discourages productive investment, which in turn hampers economic growth. However, real interest rate in itself might not really matter for growth performance, if lending interest rate results in higher productive investments.

INFL: INFL has statistical insignificance at 5\% level as t-stat is less than 2 and p-value surpasses .05. An increase in inflation rate of one percent would raise the existing GDP by about 6 percent. 
This positive relationship does not align with apriori expectation. Higher inflation, especially at the extreme levels is a detriment to economic growth through higher cost of commodities and lower purchasing power. Nonetheless, in reality, low levels of inflation are beneficial for economic growth as it boosts employment and affords consumers the purchasing power to buy goods and services, which boost an economy's growth.

OEXR: EXR Is statistically significant at $5 \%$ as tstat is greater than 2and p-value is beneath 0.05 . A percentage rise in exchange rate will cause about 34 percent increase in current GDP. This positive relationship is in sync with theory as higher exchange rate results in currency depreciation, which boosts exports, production and consequently economic growth in Nigeria.

DW-stat is about 2.18 which show that there is no presence of autocorrelation.

$\mathbf{R}^{2}$ : All independent variables combined explain about $70 \%$ of the changes in GDP. And after being adjusted for degree of freedom, Adjusted $\mathbf{R}^{2}$ depicts that all the independent variables explain about $42 \%$ of alterations in GDP. This is fairly representative of the importance of public finance in Nigeria.

F-stat and Prob (F-stat): All independent variables are jointly significant at about 2.51 and about $1 \%$ level respectively in explaining changes in GDP.

Table 3. Result of Bounds Test Null Hypothesis: No long-run relationships exist

\begin{tabular}{lcc}
\hline \hline Test Statistic & Value & $\mathrm{K}$ \\
\hline \hline F-statistic & 4.844284 & 7 \\
\hline \hline Critical Value Bounds & & \\
\hline \hline Significance & I0 Bound & I1 Bound \\
\hline \hline $10 \%$ & 2.03 & 3.13 \\
$5 \%$ & 2.32 & 3.5 \\
$2.5 \%$ & 2.6 & 3.84 \\
$1 \%$ & 2.96 & 4.26 \\
\hline \hline
\end{tabular}

Source: Authors Computations, (2019). E-views, 9.0

F-stat value (4.84) exceeds all upper boundaries at $1 \%, 5 \%$ and $10 \%$ significance levels, which conforms with decision criteria, so long run relationship exists.

Table 4. Long-Run Co-Integration Result Long Run Coefficients

\begin{tabular}{crrrr}
\hline \hline Variable & Coefficient & Std. Error & t-Statistic & Prob. \\
\hline \hline GREV & 0.073911 & 0.028019 & 2.637903 & 0.0173 \\
REXP & -0.095626 & 0.040652 & -2.352324 & 0.0310 \\
CEXP & -0.037640 & 0.013397 & -2.809573 & 0.0121 \\
GDS_LCU & 0.000000 & 0.000000 & 1.304573 & 0.2094 \\
RINT & 0.265653 & 0.094169 & 2.821024 & 0.0118 \\
INFL & 0.193152 & 0.084756 & 2.278920 & 0.0359 \\
OEXR & 0.342001 & 0.111832 & 3.058151 & 0.0071 \\
C & -2.376609 & 2.746247 & -0.865402 & 0.3989 \\
CointEq(-1) & -1.000272 & 0.176703 & -5.660759 & 0.0000 \\
\hline \hline Cointeq = GDP $-\left(0.0739^{*}\right.$ GREV & $-0.09566^{*}$ REXP $-0.0376{ }^{*} \mathrm{CEXP}$ \\
+0.0000 & & & \\
*GDS_LCU + 0.2657*RINT + 0.1932*INFL + 0.3420*OEXR - \\
2.3766 )
\end{tabular}

Source: Authors Computations, (2019). E-views, 9.0

Long run Result: GDP $=2.3766-0.0739$ GREV + 0.0956REXP + 0.0376CEXP - 0.0000GDS_LCU 0.2657 RINT -0.1932 INFL $-0.34200 E X R$

Table 4 presents the ARDL long-run relationship for the above model. The constant term implies that in the absence of all explanatory variables (GREV, REXP, CEXP, GDS_LCU, RINT, INFL, and EXR), economic growth rate will be positive at about 2.38 percent.

GREV: GREV is statistically significant at a rate of 5 percent with more than 2 tstat and less than 0.05 pvalues. A percent rise in government revenue will cause about 7 percent decline in current GDP in the long run. This negative relationship does not conform to apriori expectation as it indicates that government revenue was not properly utilized to yield higher economic growth for Nigeria.

REXP: REXP has statistical significance at 5\% The t-stat level is above 2 and the p-value is below 0.05 . A percentage rise in recurrent expenditure will bring about 9.6 percent increases in current GDP on a long-term basis. This implies that recurrent expenditure is essential in sustaining the future of Nigerian economy as workers are well remunerated. 
CEXP: At a rate of 5 percent, CEXP is statistically significant as t-stat is greater than 2 and $\mathrm{p}$-value less than 0.05. A rise in capital expenditure of one percent will have a significant long-term effect on the Nigerian economy by around 3.8\%thereby conforming to theoretical expectations as capital machineries go a long way to aid productive activities.

GDS_LCU: has statistical insignificance as t-stat is lower than 2 and p-value surpasses 0.05. One percentage rise in gross domestic savings will have no effect on the economy of Nigeria the future. This indicates that aggregate savings do not actually impact the economy, as what really matters is translating those savings into productive investments for sustained long-term benefits.

RINT: RINT is statistically important at $5 \%$ as t-stat is above 2 and p-value is below 0.05. A percent rise in real interest rate will yield about 26.6 percent decrease in current GDP. This negative relationship conforms to theory because higher interest rates it will raise the cost of borrowing, which will then discourage lending for productive investment ventures. This negatively affects long-tern national growth.

INFL:INFL has a statistical importance of $5 \%$ as tstat is above 2 and p-value is below 0.05 . One percent rise in inflation rate will bring about 19.3\%decreases in current GDP. This negative relationship conforms to apriori expectation as high inflation reduces individuals' purchasing power, which makes it more expensive to buy products and vital utilities, thus adversely affecting growth levels of the Nigerian economy in the future.

EXR: EXR is statistically significant at $5 \%$ level as t-stat exceeds 2 and p-value is lower than 0.05. A percentage rise in exchange rate will cause about 34.2 percent decrease in current GDP. This negative relationship does not align with theory as higher exchange rate causes depreciation of the naira, which is theoretically meant to boosts export levels. However, for a country like Nigeria that is more of a consuming than a producing nation, this currency depreciation will not necessarily boost exports (due to greater imports), which then negatively affects production and growth levels of the economy in the long run.

\section{ERRORCORRECTION MODEL (ECM)}

ECM is negative, indicating error convergence. Therefore, in the next period, about $100 \%$ of the errors produced during this period will be corrected.

Fig.1. Model Selection Criteria

Akaike Information Criteria (top 20 models)

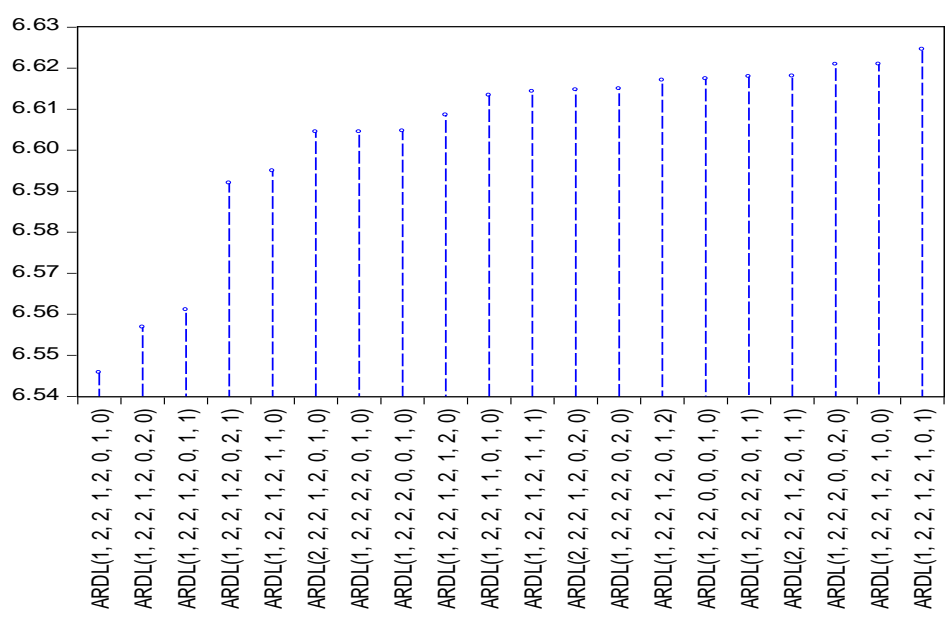

Fig.1 depicts model selection criteria graph. This shows various combinations of lags that minimize Akaike information, where E-views have helped to select the lowest and best criteria $(1,2,2,1,2,0,1$, and 0).

Fig.2. Stability CUSUM Test

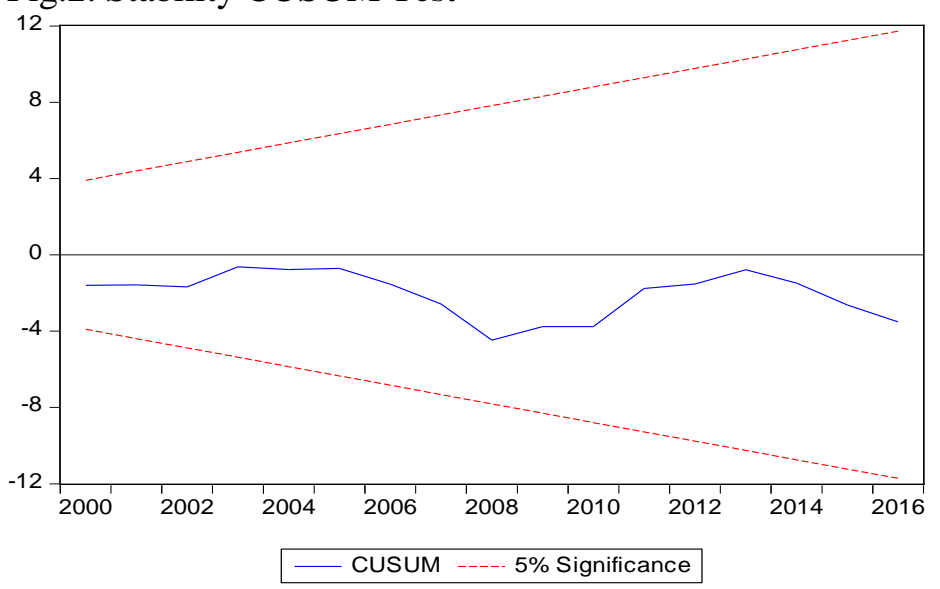

Fig.2 presents graph using Cumulative sum (CUSUM) test. The line must lie between upper and lower boundaries. The graph satisfies this condition; therefore, it is significantly stable at 5\% level. 
Lags: 2

Table 5. Granger Causality Test

\begin{tabular}{|c|c|}
\hline Null Hypothesis: & $\begin{array}{c}\text { F- } \\
\text { Obs Statistic Prob. }\end{array}$ \\
\hline $\begin{array}{l}\text { GREV does not Granger Cause } \\
\text { GDP } \\
\text { GDP does not Granger Cause GR }\end{array}$ & $\begin{array}{rr}35 & 0.707730 .5008 \\
\text { REV } & 0.383770 .6846\end{array}$ \\
\hline $\begin{array}{l}\text { REXP does not Granger Cause } \\
\text { GDP } \\
\text { GDP does not Granger Cause RE }\end{array}$ & $\begin{array}{rr}35 & 0.335260 .7178 \\
\text { EXP } & 0.216820 .8063\end{array}$ \\
\hline $\begin{array}{l}\text { CEXP does not Granger Cause } \\
\text { GDP } \\
\text { GDP does not Granger Cause CE }\end{array}$ & $\begin{array}{rr}35 & 0.230770 .7953 \\
\text { EXP } & 0.470190 .6294\end{array}$ \\
\hline $\begin{array}{l}\text { GDS_LCU does not Granger } \\
\text { Cause GDP } \\
\text { GDP does not Granger Cause } \\
\text { GDS_LCU }\end{array}$ & $\begin{array}{r}340.007530 .9925 \\
0.920210 .4098\end{array}$ \\
\hline $\begin{array}{l}\text { RINT does not Granger Cause } \\
\text { GDP } \\
\text { GDP does not Granger Cause RII }\end{array}$ & $\begin{array}{cc}35 & 0.570880 .5710 \\
\text { INT } & 0.855960 .4350\end{array}$ \\
\hline $\begin{array}{l}\text { INFL does not Granger Cause } \\
\text { GDP } \\
\text { GDP does not Granger Cause INF }\end{array}$ & $\begin{array}{rr}35 & 0.383780 .6846 \\
\text { IFL } & 1.606540 .2174\end{array}$ \\
\hline $\begin{array}{l}\text { OEXR does not Granger Cause } \\
\text { GDP } \\
\text { GDP does not Granger Cause OE }\end{array}$ & $\begin{array}{rr}35 & 0.87 \\
\text { EXR } & 0.49\end{array}$ \\
\hline $\begin{array}{l}\text { REXP does not Granger Cause } \\
\text { GREV } \\
\text { GREV does not Granger Cause } \\
\text { REXP }\end{array}$ & $\begin{array}{r}352.030230 .1490 \\
2.051780 .1462\end{array}$ \\
\hline $\begin{array}{l}\text { CEXP does not Granger Cause } \\
\text { GREV } \\
\text { GREV does not Granger Cause } \\
\text { CEXP }\end{array}$ & $\begin{array}{r}35 \\
2.768580 .0788 \\
1.140630 .3331\end{array}$ \\
\hline $\begin{array}{l}\text { GDS_LCU does not Granger } \\
\text { Cause GREV } \\
\text { GREV does not Granger Cause } \\
\text { GDS_LCU }\end{array}$ & $\begin{array}{r}34 \\
1.760350 .1899 \\
6.818910 .0037\end{array}$ \\
\hline $\begin{array}{l}\text { RINT does not Granger Cause } \\
\text { GREV } \\
\text { GREV does not Granger Cause } \\
\text { RINT }\end{array}$ & $\begin{array}{r}350.137950 .8717 \\
2.445560 .1038\end{array}$ \\
\hline $\begin{array}{l}\text { INFL does not Granger Cause } \\
\text { GREV } \\
\text { GREV does not Granger Cause II }\end{array}$ & $\begin{array}{rr}35 & 0.230930 .7952 \\
\text { INFL } & 1.543240 .2302\end{array}$ \\
\hline $\begin{array}{l}\text { OEXR does not Granger Cause } \\
\text { GREV } \\
\text { GREV does not Granger Cause } \\
\text { OEXR }\end{array}$ & $\begin{array}{r}35.364900 .0102 \\
1.905480 .1663\end{array}$ \\
\hline $\begin{array}{l}\text { CEXP does not Granger Cause } \\
\text { REXP } \\
\text { REXP does not Granger Cause } \\
\text { CEXP }\end{array}$ & $\begin{array}{r}35 \\
2.314860 .1162 \\
1.220780 .3092\end{array}$ \\
\hline
\end{tabular}

REXP does not Granger Cause

GDS_LCU

7.048490 .0032

RINT does not Granger Cause

REXP

352.256740 .1222

REXP does not Granger Cause RINT 2.037130.1481

INFL does not Granger Cause

REXP

350.358600 .7016

REXP does not Granger Cause INFL 1.313160 .2840

OEXR does not Granger Cause

REXP

REXP does not Granger Cause

OEXR

353.683650 .0371

GDS_LCU does not Granger

Cause CEXP

CEXP does not Granger Cause

GDS_LCU

1.641520 .2106

RINT does not Granger Cause

CEXP

CEXP does not Granger Cause RINT 2.470940.1015

INFL does not Granger Cause

CEXP

$35 \quad 0.020570 .9797$

CEXP does not Granger Cause INFL 2.052170.1461

OEXR does not Granger Cause

CEXP

353.613960 .0392

CEXP does not Granger Cause

OEXR

0.900330 .4171

RINT does not Granger Cause

GDS_LCU

$34 \quad 0.135260 .8740$

GDS_LCU does not Granger Cause

RINT

1.811930 .1813

INFL does not Granger Cause

GDS_LCU

GDS_LCU does not Granger Cause

INFL

340.125210 .8828

0.777950 .4687

OEXR does not Granger Cause

GDS LCU

GDS_LCU does not Granger Cause

OEXR

341.876270 .1713

0.746650 .4828

INFL does not Granger Cause

RINT

352.875980 .0720

RINT does not Granger Cause INFL $\quad 0.199750 .8200$

OEXR does not Granger Cause

RINT

RINT does not Granger Cause

353.133070 .0581

OEXR

1.941120 .1612

OEXR does not Granger Cause

INFL

$35 \quad 1.689410 .2017$

INFL does not Granger Cause OEXR 0.460250.6355

Source: Authors Computations, (2019). E-views, 9.0

Null Hypothesis for Granger Causality: The dependent variable is not caused by an independent variable. 
Alternativehypothesis: The independent variable is responsible for the dependent variable.

Decision Criteria:When p-value is below 0.05, the variable is important, then granger makes the variable dependent, so we reject the null and consider the alternative hypotheses, and vice versa. Independent variable allows the dependent variable not to granger.

The causality test of Granger demonstrates that GEXP granger causes GREV from Table 3.5. However, since $\mathrm{p}$-value $<0.05$, GREV granger causes GDS LCU, so the null that GREV does not granger causes GDS LCU is to be dismissed and the alternative is adopted. GDS LCU, however, does not cause GREV to granger as its p-value exceeds 0.05.

OEXR granger also causes GREV with p-value < 0.05 , thus rejecting the null that OEXR does not granger causing GREV while accepting the option. In the meantime, GREV is not causing OEXR to granger.

In addition, GDS LCU is caused by REXP granger, whereas GDS LCU does not cause REXP. OEXR granger also causes REXP while REXP does not cause OEXR to granger. Again, GDS_LCU granger causes CEXP and CEXP likewise granger causes GDS_LCU. Lastly, OEXR granger causes CEXP whereas CEXP does not granger cause OEXR.

The remaining variables do not granger cause each other from both sides: GREV and GDP; REXP and GDP; CEXP and GDP;GDS_LCU and GDP; RINT and GDP; INFL and GDP; EXR and GDP; REXP and GREV; CEXP and GREV; RINT and GREV; INFL and GREV; CEXP and REXP; RINT and REXP; INFL and REXP; RINT and CEXP; INFL and CEXP; RINT and GDS_LCU; INFL and GDS_LCU; EXR and GDS_LCU; INFL and RINT; EXR and RINT; and OEXR and INFL.

\section{Discussion of Results}

\subsection{Statistical Analysis of the Three Hypotheses}

The hypotheses developed in this study weretested using studentt-statistics. The significance rate of the analysis for a two tailed test is 5 percent.The decisionprinciple is to accept the null hypothesis if thecritical / $t$-value is lower than the estimated value, otherwise it will reject the null hypothesis. In other words, using the student t-test (t-statistical), it is said that a parameter is statistically insignificant if $t^{*}$ is below 95 percent (or 5 percent) confidence levels below the table value. Thus;

$\mathbf{H}_{\mathbf{0}}$ : The null hypothesis $\beta_{0}=0, \mathbf{H}_{\mathbf{1}}$ : The alternative hypothesis $\beta_{1} \neq 0$

\section{Hypothesis one:}

$\mathrm{H}_{0}$ : Revenue from government has no significant impact on economicgrowth inNigeria.

In the 3.4 long-run tables, GREV is statistically significant at a rate of 5 percent with more than $2 \mathrm{t}$ stat and less than $0.05 \mathrm{p}$-values.A percent rise in government revenue will cause about 7 percent decline in the long term, GDP.

The null hypothesis is therefore rejected.

\section{Hypothesis two:}

$\mathrm{H}_{0}$ : Government expenditure hasno significant impact on Nigeria's economic growth.

In the long-run table 3.4, a percentageincrease in recurring spending would result in a long-term rise of 9.6 percent in real GDP.It means that recurrent investment plays avital role in maintaining the future Nigerian economy as well remunerated workers.

In the long run table 3.4 , the one percent increase in CEXP will have a positive long-term effect on the Nigerian economy by about 3.8\%, thereby conforming to theoretical expectations as capital machineries go a long way to aid productive activities.

Therefore the null hypothesis is rejected, expenditure ofgovernment has significantly impacted on economic growth of Nigeria although not substantially.

\section{Hypothesis three:}

$\mathrm{H}_{0}$ : Gross domestic savings by government has significant impact on economic growth in Nigeria.

Finally, long-run table 3.4 shows that a percentage increases in the gross domestic savings will have no influence on Nigeria's economy.This indicates that aggregate savings do not actually impact the economy, as what really matters is translating those savings into productive investments for sustained long-term benefits.

Hence, We accept the nullhypothesis. It is therefore concluded that the GDS did not have a significant impact on the development of Nigeria. 


\section{Conclusion}

Based on the results we conclude that if GREV is increased, it will lead to economic growth since it implies more available income to spend on essential products and utilities needed in the economy, REXP plays a vital role in sustaining the Nigerian economy because when workers are well remunerated they will put in more effort in the services they provide which will aid in economic growth, CEXP will positively impact on Nigeria's economy only if it is channeled to capital machineries since capital machineries go a long way to aid productive activities.Not the least GDS will only matter in Nigeria's economic growth if savings are converted for continuous long-term advantages into productive assets.

\subsection{Recommendation}

The following recommendations are given, based on the findings above:

1. Government should ensure that in allocating funds at various levels of government that there are no diversions which could negatively impact on GDP. (Proper check \& balance)

2. It is imperative that government should ensure it makes sound monetary and fiscal policies regarding public funds that do not distort the economic incentives.

3. Nigeria's government can encourage tax saving in the nation through multiple taxexempt investment schemes and programs. In exchange, governments can invest their earned assets in the country's different development initiatives that assist create a better economy.

4. To guarantee aggregate efficient public expenditure, Nigeria's government should guarantee optimum composition of inputs (capital and labour) from the public sector.

\section{Acknowledgements:}

We want to acknowledge Covenant University Center for Research, Innovation and Development (CUCRID) for provision of enabling environment for this research.

\section{References:}

1. Ajibola, R. (2008). Public Finance; Principles and Practice (2nd Edition ed.). Akoka, Lagos, Nigeria: AVL Publishing.
2. Barrios, S., \& Andrea, S. (2008). DirectorateGeneral Economic and Financial Affairs. Retrieved July 7, 2019, from http://ec.europa.eu/economy_finance/publicatio ns

3. CBN Statistical Bulletin. (2018). Annual Statistical Bulletin. Retrieved September 29, 2019, from Annual Statistical Bulletin: www.cbn.gov.ng

4. Cheyo, L. (2015, May 12). Linkedin. Retrieved September 28, 2019, from Linkedin Website: https://www.linkedin.com

5. Coskun, Y., Unal, S., Murat, E. H., \& Talat, U. (2017). Capital market and economic growth nexus: Evidence from Turkey. Science Direct , 19-29.

6. Dalton, H. (1922). Principles of Public Finance (4th Edition ed., Vol. 1). Allied Publishers.

7. Doyle, M. (1994). The History of the Theory of Public Finance. 75-78. (R. A. Musgrave, \& P. T. Alan, Eds.) Great Britain: THE MACMILLAN PRESS LTD.

8. Kamiguchi, A., \& Toshiki, T. (2019). Public Investment, public debt, and population aging under the golden rule of public finance. Science Direct , 110-122.

9. Okoye, L. U., Omankhanlen, A. E., Okoh, J. I., Ese, U., \& Ado, A. (2019). Government Expenditure And Economic Growth: The Case Of Nigeria. Proceedings of SOCIOINT 20196th International Conference on Education, Social Sciences and Humanities, (pp. 11841194). Istanbul, Turkey.

10. Okunola, F.A., Godswill, O. \&Omankhanlen (2019). Financing Gap Model Using Stepwise Regression. Investment Managemt snd Financial Innovations, 16(3), 157-166. doi:10.21511/imfi.16(3).2029.15

11. Ola, R., \& Offiong, J. O. (1999). Public Financial Management in Nigeria (1st Edition ed.). (M. O. Basil Jomoh, Ed.) Lagos, Nigeria: AMFITOP.

12. OmankhanlenA.E.,Ogaga-Oghene J.O.,Obarisiagbon E.I \&Okorie U.E(2014). The Nigerian Governement Expenditure on Human Capital. European Journal of Business and Social Sciences, 3 (7), 01-13.

13. Oyedele, T. (2016, January 11). A Review of the Major Tax Event of the Year. Retrieved August 14, 2019, from https://www.pwc.com

14. Oyinlola, M. A., \& Olusijibomi, A. (2013). Public Expenditure and Economic Growth: Futher Evidence from Nigeria. Journal of 
Economics and International Finance, 5 (4), 146-153.

15. Patra, S. K., Dogga, M. S., Mahandra, K. B., \& Avipsa, M. (2017). Revisiting the Casual nexus between savings and economic growth in India: An empirical analysis. Science Direct , 380391.

16. Rabia, N., Mumtaz, A., Mamoona, I., \& Ayza, S. (2013). Does Fiscal Policy Matters forGrowth? Empirical Evidence from Pakistan. International Journal of Economics and Finance .
17. Smriti, R. (2017). Share Your Essay. Retrieved September 29, 2019, from Share Your Essay: http://www.shareyouressays.com

18. Sobiech, I. (2019). Remittances, finance and growth. Science Direct , 44-59.

19. Szarowska, I. (2016). Quality Public Finance and Economic Growth in Czech Republic. 1373-1381.

20. Zeyneloglu, I. (2018). Fiscal policy Effectiveness and the golden rule of public finance. Science Direct , 85-93. 